\title{
慢性硬膜外血腫
}

\author{
自験 2 例と文献的考察
}

松本 隆·永井整・杉山 尚武*·大野 正弘・神谷健・福岡 秀和
梅村
訓

\section{Chronic Epidural Hematoma}

Report of Two Cases

\author{
Takashi Matsumoto, Hajime Nagai, Naotake SugiYama*, Masahiro Ohno, \\ Ken KAMIYA, Hidekazu FUKUOKA and Satoshi UMEMURA
}

Department of Neurosurgery, Nagoya City University, Nagoya; ${ }^{*}$ Department of Neurosurgery, Nagoya East General Hospital, Nagoya

\begin{abstract}
Two cases of chronic epidural hematoma are reported. Case 1, a 15-year-old female, was admitted with complaints of mild headache and hyposmia, and with computerized tomography (CT) findings of suspected epidural mass. Thirty-six days before admission, she fell from a motorcycle. Surgery revealed that the mass was an epidural hematoma with calcification. Case 2, a 17-year-old male, was admitted as the CT scan revealed an epidural mass. Thirty-one days before admission, he was involved in a traffic accident. Neurological examination revealed mild left motor weakness. Surgery confirmed that the mass was an epidural hematoma. Many atypical epidural hematoma have been reported. Some cases were reported as chronic epidural hematoma, and the others were reported as delayed epidural hematoma. However, the difference between the chronic epidural hematoma and the delayed epidural hematoma is not clear. In this paper, the chronic epidural hematoma and the delayed epidural hematoma are determined as follows. 1) Chronic epidural hematoma: Time interval between injury and operation is 14 days or more. Chronically increased intracranial pressure (ICP) is the main sign in these cases. In some cases, no symptoms or signs are observed. The hematoma is accompanied by a membrane or calcification. 2) Delayed epidural hematoma: Time interval between injury and operation is within 14 days. The chief complaint is the progressive ICP elevation sign.
\end{abstract}

Key words: chronic epidural hematoma, delayed epidural hematoma, neomembrane
Iはじめに
II 症
例

最近我々は, 受傷後 1 力月以上を経過してから手術を施 行した2 例の硬膜外血腫を経験したので，これを報告する とともに，非定型的な経過をとる硬膜外血腫に関し若干の 文献的考察索加える。

\author{
<症例 $1>15$ 才，女子 \\ 家族歴・既往歴：特記事項なし \\ 現病歴：1982年6月28日, ハイクで走行中, 後部座席か \\ ら転落した，受傷直後に意識を失ったが，30分後に汢意樴
}




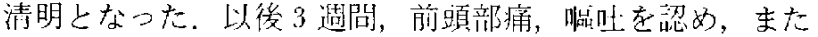

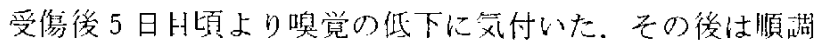
な経過をとり，3週目に退院したが，軽い前䫓部痛，嚊営 低下を訴えたため，8月2日名古屋束市民抦院内科で

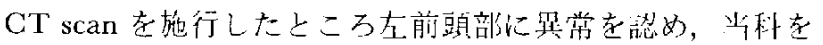
紹介され入院した。

入院時所見：嗅喾の低下上軽度の前頭部痛以外，神程学 的には異常を認めなかった。

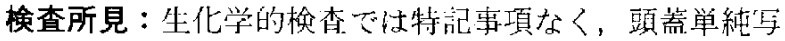
でも胃折線，石灰化などの買常所見は認めなからた。CT scan では左前頭部に厚さ約 $2 \mathrm{~cm}$, 直径約 $4 \mathrm{~cm}$ の山レンズ 状の mass 認め，中心は high density，周团は low density で，硬膜側は膜様に high density を元した(Fig. 1).

手術：8月 6 日，受傷㣪40H目に左前頭側頭開頭術を施 行した. Mass は硬膜側に厚さ $2 \mathrm{~mm}$ 程度の石灰化を伴一

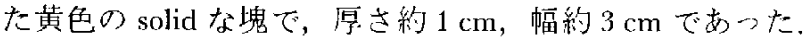
液体成分は涩めなかった。

病理学的所見：硬膜側の石庆化部分には骨芽細胞, 骨細 胞を認めた（Fig. 2A)。血腫内容物には好中球，リンパ球 などの笑症性細胞の浸潤と結合織の增生，毛細血管の新 牛。消血在認め, sinusoidal channcl layer と思われた (Fig. 2B).

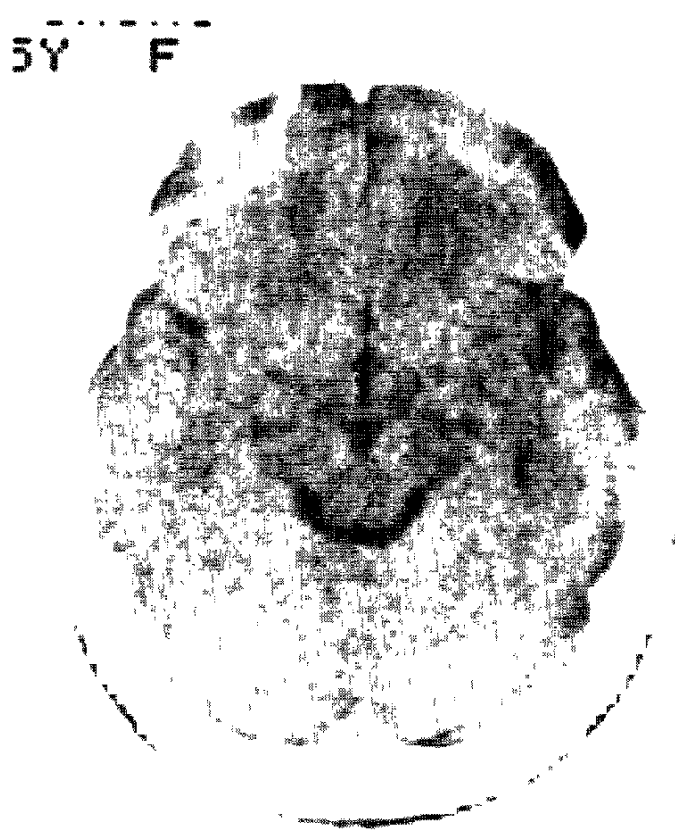

Fig 1 Case 1. Plann computerized tomography scan 35 days after injury showing a left epidural hematoma with calcification.

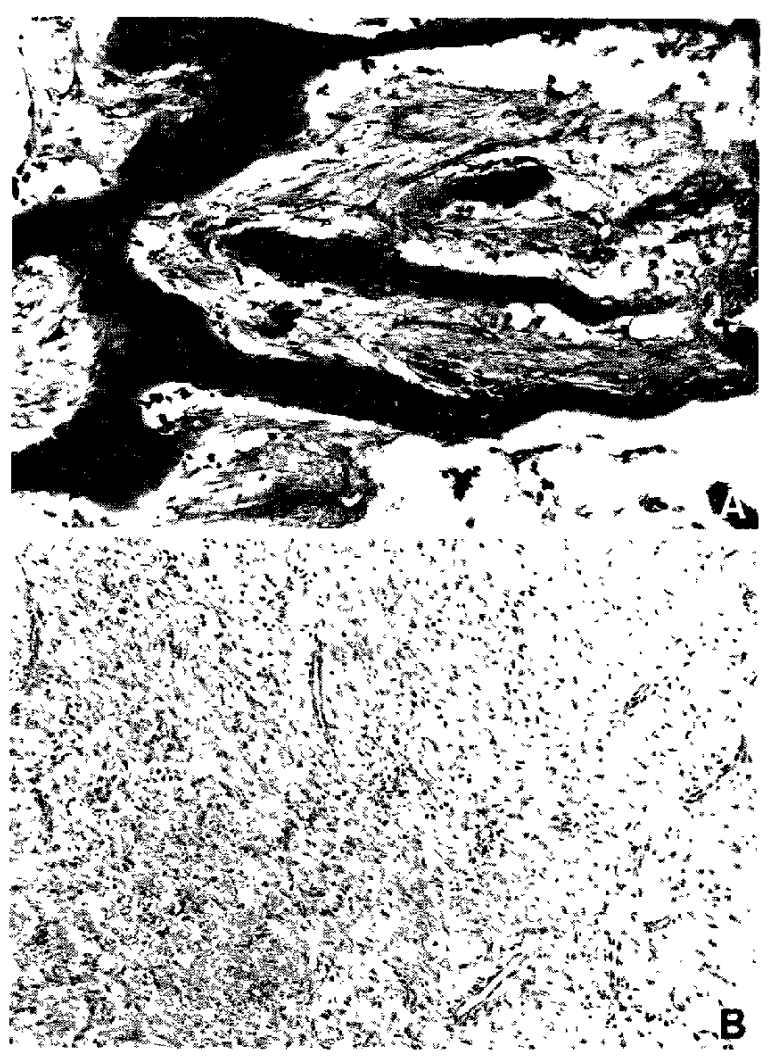

Fig 2 Case 1 A: Photomicrograph showing ossufication of granulation tissue on the dura mater B Photomicrograph showing granulation tissue with capillary. HE stain, $\times 150$

患者仕術後12日月に全治退院した。

<症例 $2>17$ 才, 男子

家族歴，既往歴：特記事項なし

現病歴：1983年7月25日，自転車に乗っていて本上接触 し，転倒した，受賃直後より軽度の意識障害と嘔叶があ り，救急止で近医に入院した。受傷後 3 日间，軽度の意識 障害在認めたが，それ以後軽快した。しかし 8 月 $23 \mathrm{H}$ ，退 院を控えて念のためCT scan を施行したところ右頭頂側 頭部に凸レンズ状の mass 老热めたため，手钿を目的とし て，8月25日当科を紹介さ机入院した。

入院時所見：自覚症状としては特になく，他覚的に左上 下肢にわずかな筋力低下在認力た。

検查所見：生化学的検查で性特記事項なく，頭蓋単純写 で右頭頂側韻部に长さ $3 \mathrm{~cm} の$ 線状骨折を認めた。CT scan で注右頭頂部に厚さ $3 \mathrm{~cm}$, 直烽 $8 \mathrm{~cm}$ の凸レンズ状 の mass を諗めた. Plain CTでは中心の一部がわずかに high density，その周四が iso density，硬膜側がわずかに high density 示し, enhanced CT では硬膜側が著明に 


\section{III 考察}

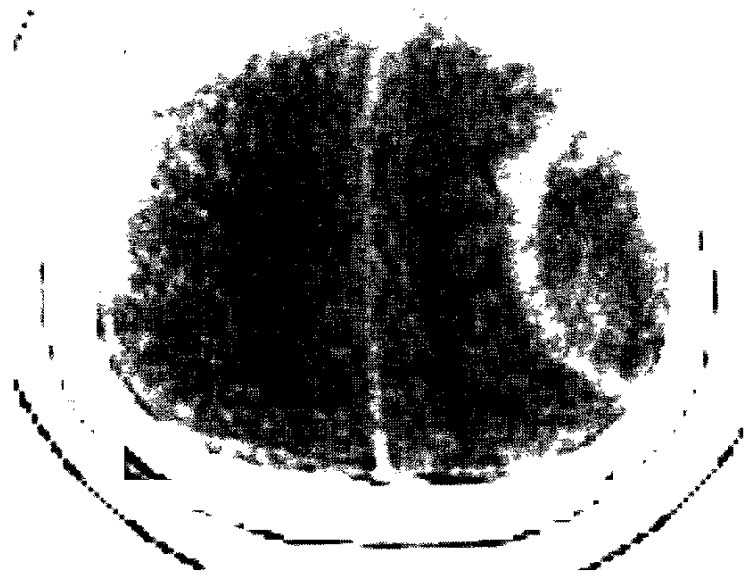

Fig. 3 Case 2. Enhanced computerized tomography scan 29 days after injury showing a right epidural hematoma. which is surrounded by a high density capsule.

enhancementされた(Fig. 3).

手術：8月25日，受傷後31月日に右頭頂側頭開韻術在施 行した，血腫は骨側に黒褐色の液体成分を，硬膜側には厚

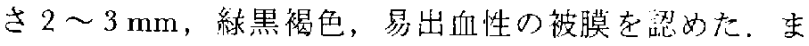
た，中間部は暗赤色の凝血塊であった。

病理学的所見：Fig. 4 亿示すごとく，全体に線維組織で 一部は硝子化していた，古い结向由来の hemosiderin の沈 着も強く，硬膜侧に汢わずかな骨縕織もみられた。去た毛 絊血管の新生を誋め, sinusoidal channel layer と思われた。

忠者は術後10日月に全治退院した。

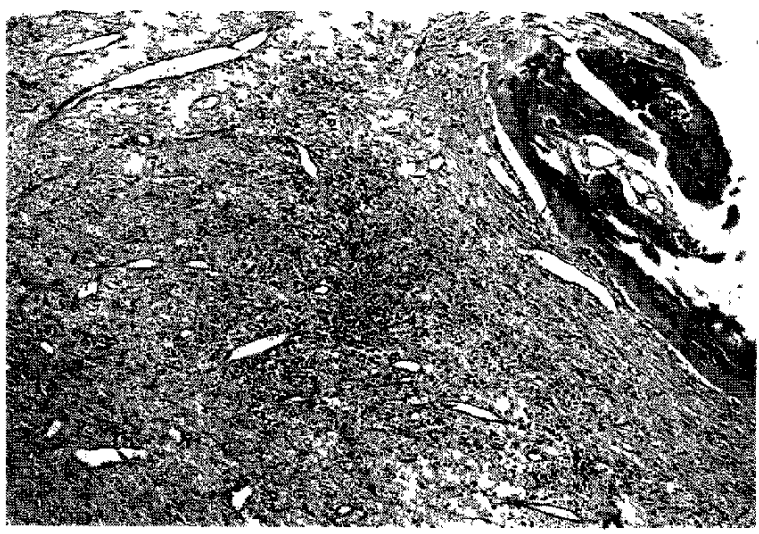

Fig. 4 Case 2. Photomicrograph of the surgical specimen showing granulation tissue and calcification. $\mathrm{HE}$ stain, $\times 150$.

\section{1. 非定型的硬膜外血腫}

硬膜外血腄の存在は方くから知られていた方，1886年 Jacobson ${ }^{11 !}$ は71例を詳細に報告し, clinical entityとしての 位置付けを行った，木疾患の定型的な監床経過は，受傷㣪 24時間以内に頭菩内压元進症状，局所脳庄迫症状示し， 叮及的速やかに血腫を除去しなければ长に至る年というも のである。しかしながら，このような定型的な経過をとら ない硬膜外向腫が存在することは，Wiesmann ${ }^{23)}$ 老初め， 多くの報告で明ら吕にされてきている、Jackson ら

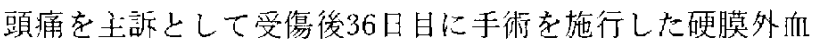
腫を chronic extradural hematomaとして報告した。また King $5^{(3)}$ 恃，受傷後24時間以上を経過してから硬膜外亚

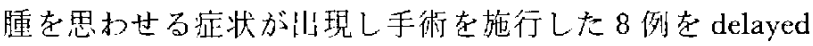
onset of symptoms due to epidural hematoma $し て$ 報告 た。 その後も非远型的な経過をとる硬膜外血腫の報告は增 加し，我々の調べえた範同では文献上84例1,3,4,7-10,13-16,18-20) であった。 このうち慢性硬膜外向腫しして塟吘されたもの は41例7 10,16,18)，遅兴性硬膜外血腫として報告されたもの は21例1,13-15,19\}であった。

\section{2. 非定型的硬膜外血腫と急性硬膜外血腫との比較}

\section{(Table 1)}

発症年齵：慢性硬膜外血腫の41.4\%，遅発性硬膜外血腫 の $52.4 \%$ が20才以下の若年者であった。一j，急性硬膜外 血腫では29.6\%が20才以下6であり，慢性，遅発性ともに 若年老に好発する傾向が琹めら扎た。

男女比：慢性硬膜外血腫の $90 \%$ ，遅発性硬膜外血腫の 90.4\%が男性であった。急性硬膜外血腫においても $93.5 \%$ が男性の゙であった。

Table 1 Summary of the differences between the atypical epidural hematomas and the acute epidural hematoma

\begin{tabular}{|c|c|c|c|c|}
\hline & $\begin{array}{c}\text { Age } \\
\text { (under 20) }\end{array}$ & $\begin{array}{c}\text { Sex } \\
\text { (male) }\end{array}$ & $\begin{array}{c}\text { Location } \\
\text { temporal })\end{array}$ & Size \\
\hline $\begin{array}{l}\text { Chronic } \\
\text { epidural } \\
\text { hematoma } \\
(41 \text { cascs })\end{array}$ & $41.4 \%$ & $90.0 \%$ & $46.5 \%$ & $\begin{array}{l}1 \times 3- \\
10 \times 10 \times 3 \\
\mathrm{~cm}\end{array}$ \\
\hline $\begin{array}{l}\text { Delayed } \\
\text { epidural } \\
\text { hematoma } \\
\text { ( } 21 \text { cases) }\end{array}$ & $52.4 \%$ & $90.4 \%$ & $37.8 \%$ & $\begin{array}{l}1.5-4.0 \mathrm{~cm} \\
\text { (thickness) }\end{array}$ \\
\hline $\begin{array}{l}\text { Acute } \\
\text { epidural } \\
\text { hematoma } \\
(167 \text { cases })^{*}\end{array}$ & $29.6 \%$ & $93.5 \%$ & $74.3 \%$ & various \\
\hline
\end{tabular}

*Gallagher et al. $(1968)^{\text {t: }}$ 
Table 2 Summary of the differences between the chronir epidural hematoma and the delayed epidural hematoma

\begin{tabular}{|c|c|c|c|c|c|}
\hline & \multirow{2}{*}{$\begin{array}{c}\text { Operated } \\
\text { time from } \\
\text { trauma } \\
\text { (within } \\
14 \text { days) }\end{array}$} & \multicolumn{2}{|c|}{$\begin{array}{l}\text { Contents of } \\
\text { hematoma }\end{array}$} & \multirow{2}{*}{$\begin{array}{l}\text { ICP } \\
\text { elevated } \\
\text { sign }\end{array}$} & \multirow{2}{*}{$\begin{array}{l}\text { Source of } \\
\text { bleeding }\end{array}$} \\
\hline & & $\begin{array}{l}\text { With } \\
\text { mem- } \\
\text { brane }\end{array}$ & $\begin{array}{l}\text { With } \\
\text { calcif- } \\
\text { cation }\end{array}$ & & \\
\hline $\begin{array}{l}\text { Chronic } \\
\text { epidural } \\
\text { hematoma } \\
\text { ( } 41 \text { cases })\end{array}$ & $5.0 \%$ & $82.9 \%$ & $24.4 \%$ & $\begin{array}{c}54.5 \% \\
\text { (chronic) }\end{array}$ & $\begin{array}{l}\text { emissary \& } \\
\text { diploic } \\
\text { veins, } \\
\text { small } \\
\text { artery }\end{array}$ \\
\hline $\begin{array}{l}\text { Delayed } \\
\text { epidural } \\
\text { hematoma } \\
\text { (21 cases) }\end{array}$ & $84.2 \%$ & $33.3 \%$ & $0.0 \%$ & $\begin{array}{c}87.5 \% \\
\text { (progres- } \\
\text { sive) }\end{array}$ & $\begin{array}{l}\text { MMA, } \\
\text { MMV, } \\
\text { emissary \& } \\
\quad \text { diploic } \\
\text { veins }\end{array}$ \\
\hline
\end{tabular}

ICP indicates intracranial pressure; MMA, middle meningeal artery; MMV, middle meningeal vein.

発生部位：掹腫が側頭部に発牛したたのは慢性硬膜外血 連で $46.5 \%$ ，晴発性硬膜外血腫で $37.8 \%$ であり，急吽硬膜 外血腫では $74.3 \%$ であった。非定型的硬膜外血腫では， 側頭部以外に生じる率が高加った。

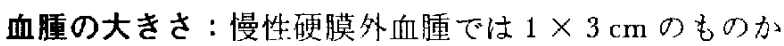
$510 \times 10 \times 3 \mathrm{~cm}$ のものまで, 遅発性硬膜外血尰では厚さ $1.5 \mathrm{~cm}$ のものから $4 \mathrm{~cm}$ のものまで瓡告されており，比較 的大きな血腫でも慢性化，暹発化する可能性があると思わ 机た。

\section{3. 慢性硬膜外血腫と暒 発性硬膜外血腫との比較( Table} 2)

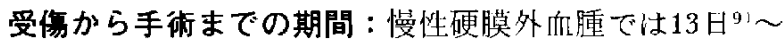
16年 ${ }^{18)}$ で，そのうち5\%のみが 2 週間以内であったのに対 し，迤発性硬膜外血腫では 3〜35Hであり，84.2\%が 2 䢛 閒以内であった。

病理学的所見：慢性硬膜外血腫では $82.9 \%$ が被膜を伴っ

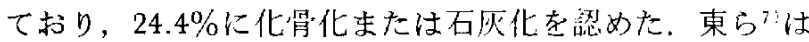
11 例の慢性硬膜外血腫中 6 例に被膜の形成を認めており， 肉腿的に被膜識別しうるのは妥傷传 3 週間以上たったも のとしている。また，3週間以内の在例に打いても硬膜表 面に肉芽形成を諗めるものもあり，これは被膜の形成過程 と考えられた。中忖 ${ }^{17}$ は受傷加ら手術まで19時間〜60日経 過した硬膜外血腫12例に関し病理学的娭討を加え，受傷後 4 日目頃から硬膜外面に接した血塊には肉限的に一層の肉 芽様組織を認め，2週間以上経過寸るとこの内芽様組織が sinusoidal channel layer を伴った被膜になると述ぶた。木 村121は生後19日目から75才にわたる44例の剖検で得られた 脳硬膜を㛟索した結果，新生览期から造肖細胞が存在し，
これは炒见期にもっとも良く発達し，成年晚期には消失す ると述べた。血腫が慢性化していく過程に扔いて若年者で は特にこのような造骨細胞が活動性上なり，化骨化を示す ものと思われる，実際，血腫の化骬化を示した症例のうち $87.5 \%$ が20才以下であった．遅発性硬膜外血腫と診断され た怔例のうち 6 例のみに血腄内容に関する記載があり，5 ち2 例19:に性被膜があった。しかしながらこの2 例の病歴 をみると，いずれも慢性硬膜外血腫の範瞦に属するものと 考えられた。

臨床释過：慢性硬膜外血腫では $54.5 \%$ が頭痛, 嘔吐, う つ血乳頭などの慢性頭盍内平克進将状を主訴としており， 進行性の頭蓋内圧充進，局所脳圧迫症状を示したものは認 められなかった。一方，遅発性硬膜外血腫では瞳孔異常を 示したもの $38.0 \%$ ，意識障害を示したもの $28.5 \%$ ，片麻怗 を示したもの $28.5 \%$ であり，症状が進行性であったものが $87.5 \%$ 占めた。

出血源：慢件硬膜外血腫の出血源として, 永井ら ${ }^{16)}$ は板 間静脈㧍よび小動脈枝が破綻をきたして血腫を形成し，こ れがさらに emissary veinの出血を誘発する上した。东た Iwakuma $ら^{91}$ は，21例中 4 例が静脈性，5例が中硬膜動脈

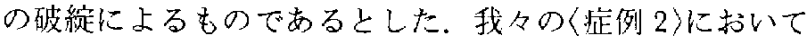
は，頭蓋単純写上線状骨折および骨のひずみが認められ， 板問静脈からの出血がもっとも疑われた。，一方，遅発性硬 膜外血腫では中硬膜動脈抢よびその分枝と記載されている ものが $37 \%$ ，板閣静脈上したものが $31.6 \%$ ，中硬膜静脈之 したものが21.0\%であった。

以上より，我々の症例はいずれも慢性硬膜外血腫の範疇 に属するものと思われた。

\section{4. その他の非定型的硬膜外血腫}

Weaver ら ${ }^{22}$ は, 症状の怪微な 2 例の硬膜外血腫につい て手術を施行せず CTで経過を観察した上ころ，それぞれ 受傷後30日目，7䓢目に血腫が消失していたと報告してい る。立た渡辽ら ${ }^{21}$ 注，頭痛，嘔吨以外に神経学的所見のな い少量の急性硬膜外血腫をCT で経過観察したところ，無 症状となった 9 例を報告している。この 9 例中 2 例は CT 上被膜と思われる enhanced area を認め, 慢性硬膜外血腌 一移行したが，他の 7 例はこれを認めず，吸収された可能 性があるとし，その後の follow upにおいても急性増悪し た例はなかったと述べている。

\section{5. 非定型的硬膜外血腫の手術適応}

今回調べえた41例の慢性硬膜外血腫 ${ }^{7-10,16,181}$ おょよび11例 の経過観察された急性硬膜外血腫 ${ }^{21,22)}$ の報告からみると， 受傷後一定期間無症状または軽微な症.状のみであった症例 は急性増恶する可能性は低いと考えられる。そ理由とし $\tau$ ，受傷後 2 週間以上経過した硬膜外血腫は自然に吸仪さ 
机るか，またはそれまでに压が十分 compensateされて mass としての影響が少なくなるためと思われる。これは， 被膜形成後も急性增患したり，石雨化した被膜が頻発する epilepsy の原团となりうる2!慢性硬膜下血腫と比較して興 味の持たれる点である，以上より，無症状または症状が倝 峳な硬膜外血腫は急性，慢性を問わず経遄観察してもよい と思われる。しかしながら，受傷後 2 週間までは遅発件硬 膜外血腫のごとく急性増琹の可能性があり，この間は症状 が急変したときには速やかに血腫除去術を施行できるよ う，厳重な観察下におくことが重要であるう。

\section{6. 非定型的硬膜外血腫の成因}

Ford らうはイヌで実験的に硬膜外血腫索作製し，(1)血腫 量がテント上容積の20\%以下の場合，(2)血腫が側頭部以外 に生じた場合，(3)血腫形成速度の迋い場合，(4)生体側の代 償能的が大きい場合には非定型的な経過をとる叮能性があ ることを示した，Fankhauser ら゙は，受傷直後のCTでは 硬膜外血腫を認めす，一定期間経過したのちに怔状の増重 を梁め，再度 CTを行ったところ莄膜外血腄を諗めた 2 例 を報告しており，痁状発現が暒れた理由は骨折楾からの血 淮の流出, 骨と硬膜の強い療着, 低厅の出向源からの出 血，骫浮腫などにより血腫の増大が䐅れたためとしてい る。また，硬膜外血腫が白然吸収される機序に関して詳述 した報告はないが，可能性として(1)骨折部から頭蓋外人と 血腫が流出し，頭菩外で吸収される場合，(2)血腫被膜から 吸収される場合，(3)硬膜が裂けているために血腫が硬膜下 腔へ流出し，吸收される場命などが考えられる。このよう な自然吸収例は，CT 出現以前には症状が軽微で経過観察 しているうちに自然に軽快したのであろう。また，そのよ うな症例のうら吸収されずに石灰化したり器筫化したりし たものが日時経てなんらかの症状を示したり，その他の 理由で精查され発見されたものが慢性硬膜外血腫として報 告されていたと考えられる，今後 CT の普及とともにこれ ら非定型的な経過をとる硬膜外血腫の報告は増加するもの と思われる，我々も症例を重双，その吸収機序，手術適応 などに関しさらに㛟討を加えて行きたい．

\section{IV ま と め}

受傷後40日目および31日目に手術を施行した慢性硬膜外 血腫 2 例について報告し，非定型的な経過をとる硬膜外血 腫に関し若下の文献的考察を加えた。

\section{文献}

1) Adcloye A, Onabanjo SO: Delayed posttraumatic extradural haemorrhage: A case report. East Afr Med J 57: 289-292, 1980

2) Afra D: Ossification of subdural hematoma. Report of two cases. J Neurosurg 18: 393-397, 1961

3) 伴野純嘉, 四中靖通, 小林計理, 宮崎雄二: 石隶化便膜上 血腫の手術経験例。手術 24: 503-511, 1970

4) Fankhauser H, Kiener M: Delayed development of extradural haematomas. Acta Neurochir (Wien) 60: 29-35, 1982

5) Ford LE, McLaurin RL: Mechanisms of extradural hematomas. J Neurosurg 20: 760-769, 1963

6) Gallagher JP, Browder EJ: Extradural hematoma. Experience with 167 patients. J Neurosurg 29: 1-12, 1968

7）東健一郎，出中忠良，宮脇唐夫：流動性内容を有寸石硬膜 外血腫. 脳上神 20: 1005-1010，1968

8）岩淵 隆，宮与里男，赤閏主和：硬膜外囊水腫の一治験 例. 滥と神 12: 364-368, 1960

9) Iwakuma $T$, Brunngraber CV: Chronic extradural hematomas A study of 21 cases. $J$ Neurosurg 38: 488-493, 1973

10) Jackson IJ, Speakman TJ: Chronic extradural hematoma. $J$ Neurosurg 7: 444-447, 1950

11) Jacobson WHA: On middle meningeal hemorrhagc. Guy Hosp Rep 43: 147-308, 1886

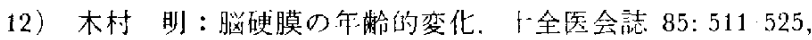
1976

13) King AB, Ghambers JW: Delayed onset of symptoms due to extradural hematomas. Surgery 31: 839-844, 1952

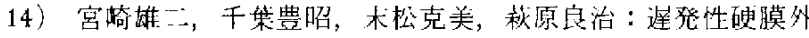
血腄についてー自家経験 10例より一。外科診療 5: 587-596, 1964

15) Moody WB: Traumatic fracture of the cranial bones. JAMA 74: $511-512,1920$

16）永少肇，林誠之：慢性硬膜外血腫について，脳と神 15: 155,1963

17）中村紀夫：慢性硬膜下血腫の発生機序。細上神 18：702709,1966

18）坂井昇，山森掅雄，種村笛己，山田弘，下川邦泰；石 灭化硬膜外血腫. 腷神外科 5: 163-167, 1977

19）土屋寿司郎，填生知則，伊藤治英，山本信二郎：湿発症性 硬膜外血隀の2 例。整災外 22: 751-754,1979

20）土屋寿司郎，西田武史，武队孡一郎，伊藤治英，山本信二 即：化骨を呈した严急性硬膜外血腫の1例，整災外 26: 293295,1983

21）渡辺英寿, 早川 勲, 十田富穂, 柳橋萬之, 佐々术亮, 中 村征郎, 中山比登志, 佐々小腾：少量の硬膜外血腫の手術適 応. 神経外傷 1: 211-216, 1978

22) Weaver D, Pobereskin L, Jane JA: Spontaneous resolution of epidural hematomas. J Neurosurg 54: 248-251, 1981

23) Wiesmann P: Ueber die modernen Indikationen zur 'T'repanation mit besonderer Berücksichtigung der Blutungen aus der Arteria meningea media. Dtsch $Z$ chir 22: 52-148, 1885

〔別刷請求先： $\mathbf{T} 467$ 名古屋市瑞穂区瑞穂町字川潑 1, 名古屋市 立大学脳神释外科, 松本隆] 